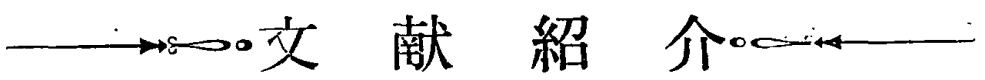

摘録采号左肩※印は複写可能濰誌を示します。複写申込み方法は 1241 ペーシ参照.

摘 録 分 類

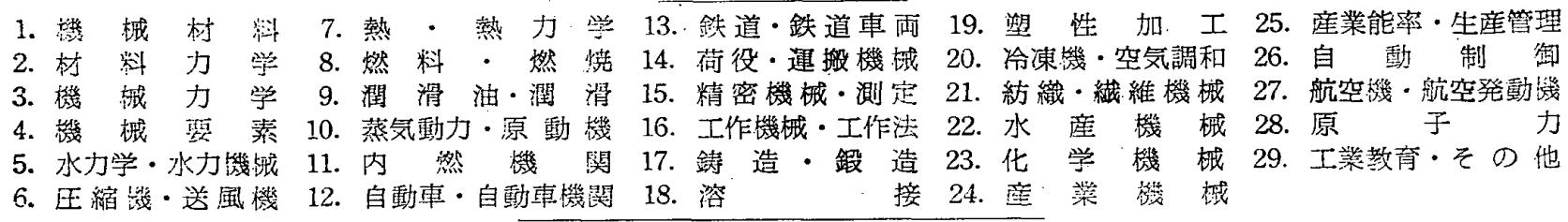

\section{$678.7: 548.52$}

[445]溶融体から球晶の結晶化 [H.D. Keith \& F.J. Padden, Jr., J. Appl. Phys., 1964-4, Vol. 35, No. 4, p. 1270〜 1285, 図 33] 冷却における溶融 体から中球晶の結晶化成長過程が多くの写真撮影によ り実験的に調へられた。ポリエチレン，ポリプロピレ ン，ポリエチレンオキサイドのような結晶性高分子 に,さらにポリスチレンやポリイソブチレン等につい ても結晶化が検討された。すなわち，アイソタクチッ ク高分子にアタクチック高分子やその他の低分子化合 物が共存すると，結晶発生成長過程で不純物としてす きまに残存し，それらが球晶形態や球晶成長速度にい ろいろの影櫭を与える。結晶の球晶充てん度は介在不 紛物の浱度に閦係し、フイブリルの断面積は次式の $\delta$

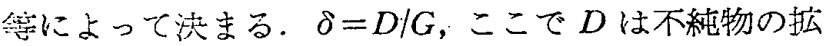

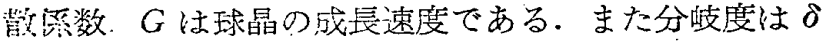
凉小さいはど大きい，不純物が存在すると球晶成辰速 度は一走でなくなり，球晶半径は成長時間の平方根に 比例するようになる。 [伊藤 勝紊]

\section{7:01}

[446]6 K 以上の温度における数種の高分子材料 の䣦的特性 [J.M. Crissman, ほか 2 名，J. Poly. Sci., 1964, Vol. 2, No. 12, p. 5075 5091, 図 12, 表 2] 各䅣の重合体の動的特性が約 $10^{4} \mathrm{c} / \mathrm{s}$ の共振 周枝のもと，6〜 $300^{\circ} \mathrm{K}$ の温度籍囲にわたって測定さ れな、实験に用いられた材料はポリエチレン, 66 ナイ ロン, 3 種のメタクリレートエステル系重合体, およ び 5 種のポリアルファオレフインとそれに属する重合 体てある。

奏积の結喿，ポリメチルメタクリレートとポリエチ ルメタクリレートの低温緩和現象はそれそれ $6^{\circ} \mathrm{K}$ お よび $52^{2} \mathrm{~K} て ゙$ 現われた。これらはエステル側鎖の炭水 化物の部分の形状が変化して再配列定起こしたために 生したたのであろう。ポリプロピレン, 塩化ビニル, ポリブロピレンオキサイト，ポリイソブチールメタク リレートなどでは $23^{\circ} \mathrm{K}$ 付近で非常に鶋心緩和現象が 胃ら礼，66ナイロンもこの傾间代認为られるようであ る.こ礼に対して 4-メチルペンタンー1 では剑いピー クが $25^{\circ} \mathrm{K}$ 付近で現われたが現在のとこらまだをの原 因となる機棈はよくわかっていない，なお $77^{\circ} \mathrm{K}$ 以下 の温度ではポリェチレンもポリブテンもともに緩和現

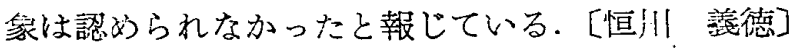

678.745.3.01:541.66.08

[4.47]ポリアクリロニトリルのガラス転移点に対す
る分子量依存性 [R.B. Beereers, J. Poly. Sci., 1964, Vol. 2, No. 12, p. 5257〜5265, 図 2, 表 3] 分子量範围が $8 \times 10^{3}$ 〜 $3 \times 10^{6}$ にわたるポリアク ロニトリルのガラス䎐移温度が測定された。ポリアク リロニトリルは結晶性秋料であり；ガラス轾移点はそ の結晶度によって交化する。この結晶度の盖の影響を 除くために試料はすべて溶媒中で，予借実臊で得られ た最良の状態で結晶化された。そののち $50^{\circ} \mathrm{C} に$ 加熱 して溶媒含有率を $10 \%$ 程度にし，さらに $100^{\circ} \mathrm{C} に し$ て残った溶媒の大部分を除去している. 分子量の測定 は粘度法により行なわれ，ガラス転移点は屈折率と笑 験温度との関係曲線から求められた。

実験の結果，分子量妾・Mn・としガラス転移点を Tg

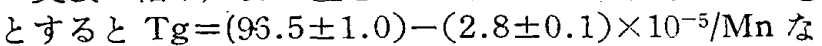
る関珇式で䘚わされることがわかり，分子量が無限大 つまり分子鎖の長さが㷛限大の試料の転移点は 96.5 \pm 1.0 であることを示している。なお, 溶媒の含有量 の影揅を調べた結果，重合体の重量百分率を $w_{2}$ とす ると $90<w_{2}<100$ の籍囲では $\mathrm{Tg}=(3.19 \pm 0.03) w_{2}$ (232士4) であることもわかった。 [恒川!義德]

\subsubsection{1:541.68}

[448]押出し成形されたポリエチレンの結晶の配向 [P.H. Lindenmeyer \& S. Lustig, J. Appl. Poly. Sci., 1965-1, Vol. 9, No. 1, p. 227〜240, 図 6, 表 i] いろいろの加工比 (Blow Ratio) で押出し成形した 時の高密度 (Marlex 50) ならびに低密度 (DXM-21) ポリエチレンの結晶の配向と二，三の物㻎的性餫につ いて述べられている。

X線的測定は Nerelcoの回折装置を用いて行なわれ た。また物理的篗は ASTM で定められた規定の方 法により行なわれ，引張強さ，破断伸び，弓裂き強さ および伸度 $10 \%$ の時の強度（弹性率と呼ぶ）が測定 された。

実験の結果，結晶の配向を検討するのに，ごく一般 的に行なわれる平故のX線回折图を用いると誤った結 論をくだす危跧のあることがわかり，ポールフイギヤ (Pole Figure) 方使用すべきであるこど强調してい る.また Blow Ratio が増せば，配向度に及はす影留 は高密度のほうがより䠃著であり，さらに引張強さな らびに弾性率惊高密度のほうが定量的には大きいが, しかし之の举動は同じであって，加工方间の值は減少 し，逆に直角方向の佪は増大することもわかった。

[恒川熟徳] 